\title{
Private Finance Serve the Real Economy and Deleveraging under Way to Analyze the Background of the Green Economy
}

\author{
Guo Wenna
}

Yinxing Hospitality Management College of CUIT, Chengdu, China

Keywords: Green Economy, Deleveraging, Strategy, Finance, Real Economy and Analysis.

\begin{abstract}
Private loans, also known as private financing, not a normative concept, in accordance with the concept of "total social financing" the people's bank raised some time ago, and from the point of view of financing sources and channels, including the financing of the real economy, the formal financial system to the real economy financing (such as bank loans) and finance (such as loans between individuals resident) economic entities inside each other, the former is called "regular financing", the latter often referred to "private financing" or "private lending . " This paper proposes the novel idea on the private finance serve that will be meaningful.
\end{abstract}

\section{Introduction}

Private lending actually can be divided into two categories: one is lending the real economy sector, such as between residents, between non-financial corporations, lending between residents and non-financial corporations and second, quasi-financial sector, including microfinance credit organizations, loan companies, industry funds, venture capital companies, security companies, pawn shops and other institutions, lending to the real sector.

According to the above defined, although private lending activity has been there since 2011, but really showing the potential of rapid development, and in addition to continuation of the previous high rate characteristics, but also show the following four new features: the expansion of (1) market size; wide (2) area; wide (3) participants; (4) the emergence of new participating institutions. The overall level of interest rates is relatively reasonable, short-term borrowing distinctive characteristics. Private lending sources of funding to individual-based, inter-enterprise lending increased. Compared with large and medium enterprises, small and micro credit problems in the real economy have been troubled by a reasonable financing problem guiding the People's Bank area financial institutions to set up small and micro economic entity dedicated window, open a small micro-enterprise loans "green channel", meet the requirements of the project in 3 days loans, and new loans for project approval in 5 days to complete. In our traditional society, there is a mutual relationship established between the clan, relatives, friends and neighbors, this relationship is not only a tool to protect against natural disasters, is an important resource for the production of social development, China is the most important traditional society a social capital. In a traditional society to a modern market economy, the process of conversion, in addition to such resources continue to play its unique social security function, or one might initially entrepreneurship and expand the main cause of social capital of the 20th century, 80-90 years of private economy start-up period even today many areas are still the most important way for people to develop entrepreneurship and initial access to external capital, accounting for the proportion of China's economy growing economy is the private entity developed on this basis, it can be said almost all of the private enterprises in the development the process of this nature have been supported by capital. In the absence of funds to support the banking system in the background, there is no capital support of this nature, our real economy on its own private accumulation is impossible to achieve such a success today. Even today, due to a market economy by the city and the erosion of social capital of this nature is being rapidly impairment, but it is still the main source of most of the external financing of private enterprises.

Natural, geographical restrictions, clan and other aspects of the relatively limited size and capacity of this nature against the risk of capital, it is difficult to meet all the survival and development of the 
private enterprises, especially some enterprise development to a certain size capital needs, but our folk effective integration of financial and the real economy is obvious.

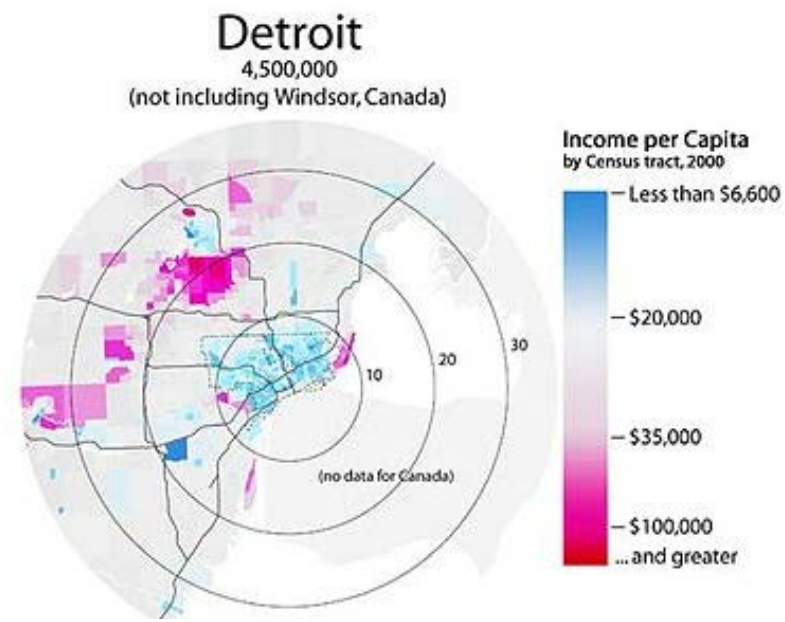

Figure 1. The Real Economy

\section{The Proposed Methodology}

Reasons for the formation of private lending trend and risk. For a long time, our country is dominated by indirect financing pattern of the importance of bank credit and the banking system is self-evident, but the delay in the bank is open to private capital, the state-owned commercial bank capital under the auspices of some degree of monopoly sources of funds in credit, the bank often biased in favor of local governments and the central enterprises and other state-owned capital. Since China market interest rate formation mechanism is not yet implemented, the central bank monetary tools are often heavy and light reserve interest rates to commercial banks steering liquidity management theory of interest rate management, once the monetary tightening, small and medium private enterprises tend to become the main bank credit crunch object.

In the non-market-oriented interest rate environment, but it is the behavior of the market economy microcosmic body. Non-bank credit entities of small loan companies, P2P as the main body, in the number of bank erosion, substantial financing for the real economy; not limited in price reflects the market interest rates. This shows that bank credit function in some aspects are missing, and now, in the field of private non-bank credit lending, the popularity seems to have the potential Forced interest rate market reform. Even the banks themselves have also through the issuance of financial products, carry out non-traditional deposit and lending business bank letter of cooperation, to circumvent regulatory restrictions on interest rates and financial regulators. In the tide of private lending, the bank entrusted loans to provide indirect financing of private lending.

Currently, the private lending involves numerous, large number of individuals, families, businesses, non-banking credit entities, and even the banking system have been involved in some areas with a "national lending" to describe is not an exaggeration. Its borrowing rate is extremely high, far beyond the normal capacity of enterprises, but also in the formal regulatory system regulatory vacuum, the central bank and the CBRC constitute unable to effectively monitor their formation, beyond the bank benchmark lending rate four times usury nor protected by law. As the debt chain, private lending, once a part of the problem, risk of rapid spread of small to corporate earnings, family harmony, ranging from financial security, social stability, has hit everyone. Of private lending has always been, in the past frequently appeared in the economically developed coastal areas, but the formation of such a large-scale capital, the spread of such the large area coverage, or unprecedented. The main reason is: First, after 30 years of development and reform and opening up, private capital together more, but less investment channels; second, Gregory huge private lending, strong temptation funds desperate owner and third, since 2008, China continued to implement tight monetary policy. This aspect leads to discrimination gradually increasing commercial bank credit; on the other hand, due to the frequent use of quantitative monetary tools at the macro-control process, but rarely use 
price-based monetary instruments while leading to financial disintermediation phenomenon is also gradually increasing. In this case, a large number of small and medium enterprises, especially private enterprises can choose the private lending market to meet financing needs.

Non-standard private lending in addition to damage the interests of both lenders and borrowers, other aspects of society has also created the shock. As it drifted outside financial supervision, the central bank is difficult to have accurate and undermine the effectiveness of macro-hedging financial control of its quantity, orientation, distribution and operation, to a certain extent; private lending interest rates too high, adding to inflationary pressures, eating operating results of the real economy, for participants normal production and life of the whole regional economy and financial operations have had a negative impact; private lending creditor and debtor established procedures, many do not have the force of law, once the two sides dispute, to judicial decisions also brought to the difficulties.

Financial Innovation. Innovative credit evaluation mechanism to solve the contradiction of information asymmetry, innovative credit approval process to meet the small micro real economy financing timeliness requirements as innovative customer service channels, improve the small micro real economy customer experience an innovative financial service products to meet with the small micro-entity economic characteristics needs innovation risk management mechanism to ensure the financial support for small and micro sustainable development of the real economy.

Although China's private finance and the real economy has maintained a good combination, but also by the protection of the law, but they always drifted away from government regulation. If in the beginning of reform and opening up, medium, their size is still small, it is not enough to run the disorder to China pose a threat to economic and social stability, then with the continuous expansion of the scale, while accelerating the urbanization process, they increasingly out of space on the original relationship by blood and clan-based regional restrictions, then this unregulated financial activities a threat to the social and political economy is more and more big, the most important is that most of the risk of the final they are borne by the government.

In 2011 Wenzhou many entrepreneurs flight or suicide, a large reason is because they cannot repay the debt in a timely and suffered results from the lender threats to personal safety, thereby not only causing serious disorder borrowers production, but from time to time lead to mass incidents ( workers to discuss wages, prime supplier to payment and other organized marches and besieged government) occurs, to maintain normal production and social order, and the government had invested heavily in a lot of the manpower involved. This government has to take responsibility unregulated situation, obviously the government would not be tolerated it is bound to be included in the regulated system to specification. At the same time, with the increasingly large scale, these unregulated "pump" of private financial activities, but also on China's macro-control policies, especially monetary macro-control policies to form a huge interference in recent years, macro-control policies the declining, in addition to the impact of the deepening of the reform of the economic system itself functions increasingly strengthened and the government misjudged the economic situation from time to time and other factors, and that these increasingly large-scale "pump" and the country constantly wandering folk financial activities has a very close relationship, abnormal fluctuations in recent years, some major agricultural commodity prices, but also closely related to these private financial activities, which are clearly the government cannot tolerate. So the biggest problem in the non-established norms and informal intermediary organizations on the basis of private finance, is that with the expansion of its size and scope, to social political and economic stability has brought more and more risks, but also greatly reduced the effect of macro-control policies to eliminate such risks, the government is bound to integrate them into normal social management systems in the past, this is the "Wenzhou financial comprehensive reform pilot area," the core content.

Enlightenment of successful experience in serving small and micro economic entities. Seen from the above several models, small and micro entity, although small in scale economy weak in strength, but as long as the right to lead, through the joint efforts of all parties, will be able to find the best financing channels to achieve the aspirations of small and micro enterprises bigger and stronger.

Government departments through various forms of government bank forum, association, and the use of nets and other electronic bank and docking platform to promote political, silver, prices and 
real-time conversation comprehensive docking for small and micro real economy needs "tailored" to develop introduce relevant policy measures, the implementation of policy support and tilt, so that the limited funds to play the greatest economic benefit for small and micro entities.

Through institutional innovation introduced competition policy as improving product targeted through product innovation, small and micro entity economy rapidly seize market opportunities; through service innovation orienteering service, enhance service relevance and effectiveness; improve the small and micro economic entities by way of security innovation credit awareness; through risk management mechanism innovation, improve financial institutions to small micro-defect rate of the real economy, tolerance and endurance. Small and micro economic entities in order to develop, we must continue to strengthen their own quality. First, pay attention to the accumulation of credit. Including corporate credit, individual and spouse, parent, child credit, etc. the second is to strengthen the standardized management. The progressive realization of small and micro economic entities by the family-style management to enterprise management change; the third is to accelerate corporate restructuring and upgrading. Eliminate backward production capacity, and actively develop high-tech products, low carbon and environmental protection products. Bank credit funds into the private lending segment, and not enough private lending banks were "kidnapped" because private lending and banks, as the two bodies do not exist in terms of debt payment. In essence, it is precisely because the existence of credit funds and private lending interest rates high fall, access to credit funds businesses or individuals lending will have a strong urge to become rent-seekers. Transfer of benefits between channel banks and private lending agency is smooth, if there is no such kidnapping behavior, there would be no banking regulators to vigorously monitor credit funds misappropriation.

\section{Conclusion}

National policies should be introduced to prevent banks were kidnapped. Nowhere private capital investment led directly to the ample private capital flows to the very attractive private lending market, the private lending hot market has a strong role in promoting. Therefore, he suggested that a good way to solve the problem of private capital, the relevant state departments should earnestly implement the non-public economy. Currently, the SMEs in the short-term speculative investments have consciousness, because they have tasted the sweetness, but they may not justify risking capital to significant risk. So we could do with the real economy, businesses can see the prospect of long-term investment and ensure their assets are safe, so you can get them to give up the role of rent. Banks in self-defense type of response measures, countries should soon provide practical legal basis for the orderly development of private finance, to further guide them towards sun, standardized development, these approaches can be transformed only through banks were kidnapped private lending fate.

The Effectiveness of The combination between the Informal Finance and the Real Economy under the Green Economy Perspective (CR1505)Funded by Sichuan Center for Rural Development Research

\section{References}

[1] Yang, Rong, et al. "Scaling-up Security Games with Boundedly Rational Adversaries: A Cutting-plane Approach." IJCAI. 2013.

[2] Danz, J. C., et al. "Virtual tissue alignment and cutting plane definition-a new method to obtain optimal longitudinal histological sections." Journal of anatomy 224.2 (2014): 85-94.

[3] Wang, Jingbin, et al. "Multiple kernel multivariate performance learning using cutting plane algorithm." Systems, Man, and Cybernetics (SMC), 2015 IEEE International Conference on. IEEE, 2015.

[4] Gzara, Fatma. "A cutting plane approach for bilevel hazardous material transport network design." Operations Research Letters 41.1 (2013): 40-46.

[5] Rossi, André, Alok Singh, and Shyam Sundar. "Cutting-plane-based algorithms for two branch vertices related spanning tree problems." Optimization and Engineering 15.4 (2014): 855-887. 